\title{
Language of Corruption in British National Corpus
}

\author{
Tantri Refa Indhiarti ${ }^{1}$, Shofiyah Salsabila ${ }^{2}$ \\ \{tantri.refa@ub.ac.id $\left.{ }^{1}\right\}$ \\ Universitas Brawijaya, Indonesia ${ }^{1,2}$
}

\begin{abstract}
The issue of corruption is under discussion as it is one of the main barriers to sustainable economic, political and social development. In order to achieve this goal, the Discourse-Historical Approach was carried out for the node word 'corruption' in BNC. Key methodological issues in CL, namely keywords, collocations, semantic preferences and concordance, have been addressed. The analysis reveals that 'bribery' is a subject discussed in the written and spoken genres of fictional and non-fictional text in the corpus. It is part of the 'world affairs' domain, where the situation is mainly distributed by young people up to 60 years old. In the distribution it is known that the node word is colloquially categorized according to its semantic preferences with other words or keywords. The pattern of interactions relates to the actors involved (i.e., government, police) in corruption, the scope of corruption including the types (i.e., bribery, nepotism, brutality) (i.e., allegation, investigation, charges). With the help of other texts on corruption semantic preferences are further analysed in order to achieve its analysis that the labelled corrupt is a consequence of interactions between the normative structure that produces meaning.
\end{abstract}

Keywords: Corruption, Discourse Historical Approach, British National Corpus

\section{Introduction}

Corruption erodes public interest and puts the social contract at risk. Corruption fuels and perpetuates the disparities and dissatisfaction that lead to fragility, violent extremism, and conflict around the world, particularly in contexts of fragility and violence (www.worldbank.org). In this case, it transcends national borders and represents political unwholesomeness on a massive scale. As a result, it is a frequent occurrence not only in developing countries, but also in developed nations, despite socioeconomic and cultural differences.

This phenomenon has been investigated in several studies. For example, anthropology is one of the disciplines which has taken an empirical approach to the different meanings of corruption. In this case, Blundo and de Sardan [1] are examining several narratives legitimising corruption in Benin, Niger and Senegal. They argue that the concept that bending rules are courteous in these countries condemns and legitimizes corruption. In the local context, a person is not called corrupt by breaking the law for personal gain but by perceiving that the personal gain resulting from illegal practice is exaggerated.

In addition to the anthropological analysis of corruption, Bakowski and Voronova [2] released a report on corruption in the European Union's legal, institutional, and policy structure (EU). It focuses on initiatives and policies at the global, regional, and local levels in eight member states: Finland, the United Kingdom, France, Germany, Italy, Croatia, Romania, and 
Bulgaria. Despite the fact that corruption is less prevalent in the EU than in the vast majority of countries and regions around the world, some EU member states are said to be affected.

These studies demonstrate that corruption takes on various meanings depending on the context. However, when the investigation is limited to a few contexts, it is insufficient; instead, examining how corruption affects individuals or groups, as well as defining the global context in which the mechanisms of corruption and the motivations that drive it, is likely to be analytically useful [3]. As a result, this study aims to fill a research void by focusing on how it is interpreted in a larger sense, such as the one provided by a corpus.

Baker [4] suggests that corruption research in the area of critical discourse analyses (CDA) is carried out to provide a comprehensive picture of the phenomenon in line with the gap filling. An alternate analytical procedure incorporating the use of concordance programs with CDA has been created to manage the data used in CDA [5]. They stated that automated analyses are insufficient and must be supplemented with manual corpus inspections and background considerations. Furthermore, CDA stresses the importance of interdisciplinary research in order to fully comprehend how language works in information transmission [6].

The use of corpus techniques for CDA is becoming increasingly important, and Stubbs is one of the first people to do so. Stubbs [7] owed Firth the insight that what people could say is socially very restricted. Recurring collocation patterns produced through the corpus method empirically show the distribution of sociologically important words in the Firthian understanding of the language [7]. Another paper recently illustrates how data from collocation can be used to analyse how problems are represented in the media: McEnery and Baker [8] analyse the reaction of two converts to Islam to the ideologically inspired murder of a soldier in central London. Research has shown that by using CL large text bodies are approachable and the key elements in discourse are identified.

This research, together with CDA and CL, adds a key discursive view in addition to other existing understandings and perspectives on corruption. It also provides an insight into how the media generally contribute to the legitimacy of corruption. Furthermore, it is practically the way to decrease corruption by giving readers knowledge of and awareness of media literacy of the nature of corruption.

\section{Research Method}

This study is classified as a qualitative study that functions to describe the language used. Corporate research has become known as the corporate language (CL). The term refers generally to a number of methods or a methodology rather than to its own language field. Baker et al. [9] portray the combination of qualitative approach and CL that utilize computer programming to identify frequent and distinguished linguistic patterns on a wide range of data as 'useful synergy methodology'.

The data of this study are retrieved from a British National Corpus (BNC) by using the node word 'corruption' and paying attention to the right and left context of the word. BNC was created as a corpus of the main language that means a great deal of planning has taken place in determining which types of texts and how many would be included [10]. This is a collection of 100 million words from a variety of sources produced by different language users. It contains written and spoken languages. A user-friendly web-based BNC web is used to search or query the data of the BNC [11]. A wide range of representations can therefore be obtained of corruption and not only one specific type of texts as they include spoken and written texts. 
The data was analysed using Wodak's [6] Discourse-Historical Approach (DHA), which combined textual and contextual levels of study. Only three of the four levels of analysis were used in this study: immediate or language or text analysis, intertextual relationships between texts and genres in other sources, and extralinguistic social context. As a result, the following steps were taken to analyse each research problem: 1) Recognizing all sentences containing the Key Word in Context (KWIC). There are times when the term 'corruption' has nothing to do with the topic at hand, such as 'data corruption'. As a result, it is critical to pay attention to some word occurrences associated with corruption as a social phenomenon; 2) determining the collocates of 'corruption' in the corpus. The collocate list for each group of phrases was then examined to see if a specific pattern or meaning groups could be deduced from the collocates. The collocate words are keywords in which the word 'corruption' co-occurs to see that the significance of corruption depends on how it interacts with other words. In order to obtain the collocative patterns of the word corruption, the researcher categorized the collectors based on their meaning group or semantic preference. In this case, an analysis of the context in which collocates are used takes into account the relationship between the corpus and other texts and the contextual aspect of DHA. The researchers have approached the subject of corruption from a variety of different angles by selecting items from the keyword list. It leads to a larger objective of examining lexical and semantic patterns in the corpus when it comes to describing corruption. Since the Bank Group has been working to reduce the pernicious effects of corruption in its client countries for more than 20 years, one aspect of this is to investigate how the semantic grouping is conceptualized in official sources, such as worldbank.org (www.worldbank.org).

\section{Result and Discussion}

In this section, corruption is examined in its lexical collectives. This was caused by an observation that various references are included in the top 100 keywords in the corpus. According to Baker [4] keywords are "words that are more frequent in corpus or text than we expected'. The objective of analysis is to give some insight into the definition of corruption.

\subsection{The Linguistic Construction of the Word 'Corruption'}

We know that the word is widely spoken in text from informative to imagination-based topics and mostly from non-academic prose and biography. Furthermore, people at all ages discuss the phenomenon, which shows that the older they are, the more corruption they concern themselves. However, this increase ceases between the ages of 45 and 59 and continues to decline after the age of 60 .

\subsection{Corruption as Perceived in BNC}

Table 1. Table of Semantic Preferences of Corruption Represented by the Collocates

\begin{tabular}{cl}
\hline Categorisation & \multicolumn{1}{c}{ Collocates/Keywords } \\
\hline References to the actor & government, police, official, bureaucracy \\
\hline \multirow{3}{*}{ References to the scope } & $\begin{array}{l}\text { bribery, nepotism, allegation, scandal, mismanagement, } \\
\text { abuse, incompetence, violence, fraud, inefficiency, } \\
\text { brutality, involvement, power, business, patronage, world }\end{array}$ \\
\hline
\end{tabular}


The table shows that the categorisation of the semantic corruption preferences represented by the collocates is divided into three namely the actor, scope, and intervention.

A range of economic, political, administrative, social and cultural factors are characteristic of corruption and symbols for broader dynamics. In this sub-chapter, therefore, corruption collocates are thoroughly described in alignment with other texts related to cases based on their semantical preference. This analysis ultimately leads to the contextual aspect of the perception of corpus corruption.

\subsection{References to the Actor}

It is known that there are four references in the corpus to actors involved in bribery: government, police, officials and bureaucracy. The following corpus samples illustrate this:

By the end of May more than 40 local government officials, politicians and businessmen had been arrested in Milan and nearby towns as the investigation of local government corruption continued (hit 26).

Trade unionists were demonstrating against sharp falls in living standards, which they blamed on the government's current austerity programme, economic mismanagement and widespread government corruption (hit 14).

Corruption exists in local and national governments, as is known in the samples (Hits 26 and 14). Citizens are more aware of corruption in the local government than the corruption of the national government. The local government is the point of contact for the administration in their behalf between citizens and their representatives.

I In this case, corruption is considered a condition under which people (politicians, government officials, companies) take advantage of their privileged positions to achieve economic gains. However, Rose-Ackerman [12] identifies the problem not in the pursuit of selfinterest, but in the way the privileged position is employed. She thus contrasts the pursuit of self-interest through competitive markets in which "it is converted into productive activities leading to the efficient use of resources" with "situations in which people use resources for both productive and profitable purposes in dividing the benefits of economic activity" [12].

The police are another party to the corruption case, as illustrated in the following samples:

The credit for securing this freedom belongs not so much to the legislators (many of whom now profess themselves appalled at developments) but to a few courageous publishers who risked jail by inviting juries to take a stand against censorship, and to the ineptitude and corruption of police enforcement (hit 12).

Er, today and every day, almost, a question of the police, at the moment, there is this business going on, er, in in London, at Stoke Newington, over the fact that, the charges against the police for corruption, being involved with all sorts of things that they shouldn't, er, and we are living through a time, where the police is [pause] having to fight a battle for its own respect (hit 15). 
The risk of corruption is enormously exacerbated by the corrupt police. Given that police are the main law enforcement agency in any society, policing corruption stops the application of the rule of law. The rule of law ceases to exist if the police sell their services to private profit. Legal corruption means that equal access is being denied [13].

Some of the high-profile police corruption incidents in the UK that Newburn found (1999). It included the suppression of evidence, the beating of suspected individuals, and the manipulation of religious evidence. These kinds of crimes have taken place in instances like the Birmingham Six (six people were convicted in 1975 for bombing two of the public pubs in Birmingham in 1991) and the Carl Bridgewater affair (in which several people were convicted in 1978 of murdering a 13-year-old boy with the convictions overturned in 1997). In both cases the defendants were released from jail because of police corruption revelations.

The example below shows another corruption actor called 'official':

Edmundo Pinto, Governor of the western Amazonian state of Acre, was shot dead in a Sao Paulo hotel on May 17, two days before he was due to testify to a congressional hearing on corruption involving officials in his own state (hit 10).

Hindess [14] reports that public officials are said to have been corrupt when conduct harms public interests, public opinion considers them corrupt, violates legal norms, deviates from normal office duties and officials are abusing their powers to maximize their income.

The corrupt behaviour of the public officials leads to the killing in Brazil of a politician taking this example out of the corpus. It was started with the 1988 killing of Chico Mendes, whose environmental movement was shocked. One of his allies is the Acre State governor elected by Jorge Viana. He pledged his people to have forest government. "Trees are our biggest resource, our vocation and patrimony, not an impediment to modernization, and we need to learn how to exploit the forest without destroying it", Viana told us (as cited in Rohter [15]). However, Mr Viana's opponents use political and judicial manoeuvres to try to deny him the further killing, during a visit to Sao Paulo, of Edmundo Pinto in his hotel room.

\subsection{The Scope of Corruption}

The scope of corruption includes how corruption is conducted through several types, factors and cost. In this case, there are several collocates as seen in the corpus: bribery, nepotism, scandal, mismanagement, abuse, incompetence, violence, fraud, inefficiency, brutality, involvement, power, business, patronage, and world.

The persistence and spread of corruption in the literature is explained by the norm-based approach, which holds that corrupt behavior generates externalities by making corruption more appealing [16]. As a result, corruption is becoming more entrenched.

Corruptions may have devastating effects on accessibility, quality and accessibility - on the basis of equality - of human rights-related goods and services according to level, prevalence and form of corruption (www.ohchr.org). The following example shows that corruption-tangled acts may constitute a violation of human rights. Corruption is a structural barrier to enjoying human rights in this case.

In fact, the great universal struggle for human rights is to be seen against the background of human suffering brought about by excessive state power, its abuses and corruption (hit 2). 
In addition, differences can exist between convictions regarding the frequency of corruption and its true impact [17]. Political turmoil shows that corruption is getting more prevalent and persistently [18]. A public servant with discretionary power must be present and followed by abuse of this power to commit corruption, extorting or bribery. The dishonest officials also collaborate in the case of bribery. There is a variety of environments for corruption, such as land rezoning, customs duties, tax collection, merit-based appointments and promotions, etc.

Corruption takes various forms. The following table is the categorisation of corruption:

Table 2. Categories of Corruption based on World Bank (2011)

\begin{tabular}{|c|c|}
\hline Categories of corruption & Description \\
\hline Bribery & $\begin{array}{l}\text { The act of dishonestly persuading someone to act in one's favour } \\
\text { by a payment or other inducement. Inducements can take the form } \\
\text { of gifts, loans, fees, rewards or other advantages (taxes, services, } \\
\text { donations, etc.). The use of bribes can lead to collusion (e.g., } \\
\text { inspectors under reporting offences in exchange for bribes) and/or } \\
\text { extortion (e.g., bribes extracted against the threat of over } \\
\text { reporting). }\end{array}$ \\
\hline Embezzlement & $\begin{array}{l}\text { To steal, misdirect or misappropriate funds or assets placed in } \\
\text { one's trust or under one's control. From a legal point of view, } \\
\text { embezzlement need not necessarily be or involve corruption. }\end{array}$ \\
\hline Facilitation payment & $\begin{array}{l}\text { A small payment, also called a "speed" or "grease" payment, made } \\
\text { to secure or expedite the performance of a routine or necessary } \\
\text { action to which the payer has legal or other entitlement. }\end{array}$ \\
\hline Fraud & $\begin{array}{l}\text { The act of intentionally and dishonestly deceiving someone in } \\
\text { order to gain an unfair or illegal advantage (financial, political, or } \\
\text { otherwise). }\end{array}$ \\
\hline Collusion & $\begin{array}{l}\text { An arrangement between two or more parties designed to achieve } \\
\text { an improper purpose, including influencing improperly the actions } \\
\text { of another party. }\end{array}$ \\
\hline Extortion & $\begin{array}{l}\text { The act of impairing or harming, or threatening to impair or harm, } \\
\text { directly or indirectly, any party or the property of the party to } \\
\text { influence improperly the actions of a party. }\end{array}$ \\
\hline $\begin{array}{l}\text { Patronage, clientelism, } \\
\text { and nepotism. }\end{array}$ & $\begin{array}{l}\text { Patronage at its core means the support given by a patron. In } \\
\text { government, it refers to the practice of appointing people directly. }\end{array}$ \\
\hline
\end{tabular}

The types of bribery, washing, greasing, nepotisms, collusions, procurement, mixing, are, as seen in the corpus. The following concordances illustrate the context of the collocates.

William Parkin, a former consultant, and Stuart Berlin, a former engineer, were imprisoned on June 2 for 26 months for bribery and corruption in connection with attempts by two employees of Teledyne Electronics, George H. Kaub and Eugene R. Sullivan, to obtain inside information on defence purchasing (hit 27).

Conspiracies or strong personal relations between business and state elites, such as corruption, nepotism or clientelism, are syndromes of underdevelopment for arbiter theorists (hit 4). 
In this case, corruption is often characterized by political corruption and corruption of bureaucracy (https://assets.publishing.service.gov.uk). Political corruption occurs at the highest political level [19]. It involves politics, government ministers, senior officials and other highranking public officials elected, nominated or appointed. It is the mistreatment of the position of the law-makers and the basic distribution of assets to a society (i.e., who make 'game rules'). Political corruption might include tailoring private sector agents' laws and regulations in exchange for bribes, awarding special firms with large public contracts or misappropriating treasury money.

During implementing public policies, bureaucratic corruption takes place. It includes appointed central or local officers and staff of the public administration. Transactions between bureaucrats and with private officers may include corruption (e.g., contracted service providers). These agents may demand additional payment for the provision of government services, pay speed cash to speed up bureaucracy, or pay bribes to allow actions which violate the rules and regulations. Corruption also involves public office interactions, such as the payment or receiving of bribes or kickbacks in order to obtain postings or a safe promotion, or the mutual exchange.

\subsection{The References of Intervention to Corruption}

Corruption is a major barrier for countries on all levels of development to sustainable economic, political and social progress. As well, corruption has helped sharply to increase inequalities in income and wealth. The commitment and leadership at the highest level is therefore essential to address corruption, ensuring that the formal requirements are met and that corrupt players are accountable effectively (www.oecd.org). In addition, the capacity of government officials and institutions to promote integrity and transparency must also be strengthened.

This case in the corpus is also extensively discussed, as evidenced by the following sample:

That Act imposed a penalty of up to two years' imprisonment, but this was altered by the Prevention of Corruption Act 1916, in certain cases to a maximum of seven years' imprisonment and a minimum of three years' imprisonment (hit 2).

The sample demonstrates the use of transparency in the fight against corruption. Other corruption collocates involved in the battle against it include investigation, commission, charges, conviction, and allegation.

The investigation has penetrated every level of society on the island and involves allegations of corruption among government ministers (hit 6).

The "allegation" can be an initial step in the investigation into corruption. Claim is a reasonably suspected bribery report that must be seriously assessed. Next there will be a decision on what to do. In this way, law enforcement officials or commissions on anti-corruption must have the knowledge in areas of corruption.

There are several anti-corruption commissions in the corpus, according to the collocate 'commission' namely the Independent Commission Against Corruption, Counter Corruption Commission. Royal Commission. It is shown in the following sample: 
The move came five days after a finding against him by the Independent Commission Against Corruption, a body which had been established in 1988 by Greiner in order to investigate alleged instances of corruption by previous Australian Labor Party (ALP) administrations.

In 1988, the Independent Commission Against Corruption (ICAC) was founded as an independent public interest protection organization, preventing breaches of public confidence and guiding the conduct of government officials in the NSW public sector (www.icac.nsw.gov.au). The ICAC is independent because it operates in the absence of political leaders, bureaucrats, any political party, or government, including investigations. The ICAC does not bear responsibility with the Minister of Government unlike most other publicly funded organisations. This is a necessary independence for the public to trust that ICAC is either not partial or subject to the government's dictates of the day. The ICAC Act and other legislation give the ICAC special powers to carry out the investigation functions that in some respects are beyond those given to the police.

\subsection{Discussion}

The corpus reveals that the types of corruption vary in terms of who is involved, how it is carried out, the degree to which it is practiced, and how it is prevented. Several methods, such as those used by anthropologists, are taken into account when studying corruption. Blundo and de Sardan [1] looked at commonly shared representations that occur outside of the individual differences associated with distribution context, informant status, and professional worldview. The semiology of corruption at two different levels is used in their analysis: the first level consists of built discussions based on argument and the second level involves the vocabulary level used. Furthermore, various indicators, including the Transparency International Corruption Perception Index and the World Bank's Global Governance Indicators were developed in Bakowski and Voronova [2]. In public opinion, transparency International Global Corruption Barometer has been the main international survey since 2003 which gathered data about the experiences and perceptions of people in corruption.

By promoting a view of corruption as a socially constructed phenomenon, the methodology emphasized in previous studies illuminates main concepts in corruption. However, the emphasis on the linguistic properties of corruption remains largely stagnant. As a consequence, in this study, which takes a critical approach to corruption discourse, the critical part of understanding corruption transfers attention to the linguistic moves in which notions of corruption are constructed. As a result, the discussion of corruption in this study is interpreted as socially controlled conflicts over meaning rather than a signification of the constantly experienced social truth.

\section{Conclusion}

The aim of this study is to explore diverse forms of corruption in order to make it an analytically useful concept for social sciences, such as political science-related critical language. Since it is difficult to measure things like corruption, it does not make that they could be ignored politically and socially. In this case, it can be shown how complex the phenomenon is because it concerns multiple collocates, such as briberies, governments and so on, by performing an 
analysis of how it is interpreted in a corpus called BNI. For example, the help of other sources related to the case observed that, in the eyes of the public and which may involve broad respect for legal procedures, the Government referred to as one of the parties participating is regarded as illegitimate.

The semantic preferences of the collocational pattern forming categorisation of a group of collocates also provide information about the complexity. The preferences address the fact that corruption is the exploitation of one's position for personal gain, which includes bribery and nepotism. Other illegal practices, such as fraud or brutality, serve to reinforce it. The actors involved in corruption and the way it takes place are also dealt with in their preferences, as they exist in many different kinds. The fact is that a variety of practices are perceived as corrupt, in different social contexts. Finally, there is a way of putting an end to corruption that decreases efficiency and increases inequality.

\section{Acknowledgment}

This paper written by Tantri R. Indhiarti and Shofiyah Salsabila is part of Ms. Salsabila's undergraduate thesis titled 'A Critical Discourse Analysis on the Construction of Corruption in British National Corpus'. In this case, Ms. Indhiarti is the thesis supervisor.

\section{References}

[1] G. Blundo and J.-P. O. De Sardan, "La corruption quotidienne en Afrique de l'Ouest," Polit. africaine, no. 3, pp. 8-37, 2001.

[2] P. Bakowski and S. Voronova, "Corruption in the European Union. Brussles: Parliamentary Research Services of the Secretariat of the European Parliament," Europa, 2017. [Online]. Available:

http://www.europarl.europa.eu/RegData/etudes/STUD/2017/608687/EPRS_STU(2017)608687_ EN.pdf.

[3] H. Marquette and C. Peiffer, "Corruption and collective action," DLP Res. Pap., 2015.

[4] P. Baker, Using corpora in discourse analysis. A\&C Black, 2006.

[5] S. Jaworska and R. Krishnamurthy, "On the F word: A corpus-based analysis of the media representation of feminism in British and German press discourse, 1990-2009," Discourse Soc., vol. 23, no. 4, pp. 401-431, 2012.

[6] R. Wodak and M. Meyer, "Critical discourse analysis: History, agenda, theory and methodology," Methods Crit. discourse Anal., vol. 2, pp. 1-33, 2009.

[7] M. Stubbs, Text and corpus analysis: Computer-assisted studies of language and culture. Blackwell Oxford, 1996.

[8] A. McEnery and P. Baker, Corpora and discourse studies: Integrating discourse and corpora. Springer, 2015.

[9] P. Baker, C. Gabrielatos, M. Khosravinik, M. Krzyżanowski, T. McEnery, and R. Wodak, “A useful methodological synergy? Combining critical discourse analysis and corpus linguistics to examine discourses of refugees and asylum seekers in the UK press," Discourse Soc., vol. 19, no. 3, pp. 273-306, 2008.

[10] L. Burnard, "XAIRA: software for language analysis," in Dagstuhl Seminar Proceedings, 2007.

[11] A. O. I. Hoffmann, T. Post, and J. M. E. Pennings, "How investor perceptions drive actual trading and risk-taking behavior," J. Behav. Financ., vol. 16, no. 1, pp. 94-103, 2015.

[12] S. Rose-Ackerman, "Political Corruption and Democracy, Faculty Scholarship Series 592." 1999.

[13] D. Bayley and R. Perito, "Police corruption," United States Inst. Peace, Spec. Rep., vol. 294, pp. $1-19,2011$. 
[14] B. Hindess, "Responsibility for others in the modern system of states," J. Sociol., vol. 39, no. 1, pp. 23-30, 2003.

[15] L. Rohter, "A Brazilian Campaign That Is All About the Jungle," New York Times, 2002. [Online]. Available: https://www.nytimes.com/2002/09/23/world/a-brazilian-campaign-that-is-all-aboutthe-jungle.html .

[16] M. J. Koehler and P. Mishra, "Technological Pedagogical Content Knowledge: A Framework for Teacher Knowledge PUNYA MISHRA,” Teach. Coll. Rec., vol. 108, no. 6, pp. 1017-1054, 2006.

[17] G. Diarra and S. Marchand, "Does Pervasive Corruption Matter For Firm's Demand for Good Governance in Developing Countries?," 2011.

[18] R. Damania, P. G. Fredriksson, and M. Mani, "The persistence of corruption and regulatory compliance failures: theory and evidence," Public Choice, vol. 121, no. 3-4, pp. 363-390, 2004.

[19] J. C. Andvig, O.-H. Fjeldstad, and A. Shrivastava, Corruption: Critical assessments of contemporary research. Report from a multidisciplinary workshop. Chr. Michelsen Institute, 2001. 